NBER WORKING PAPER SERIES

\title{
WELFARE REFORM AND HEALTH INSURANCE COVERAGE OF LOW-INCOME FAMILIES
}

Robert Kaestner

Neeraj Kaushal

Working Paper 10033

http://www.nber.org/papers/w10033

\author{
NATIONAL BUREAU OF ECONOMIC RESEARCH \\ 1050 Massachusetts Avenue \\ Cambridge, MA 02138 \\ October 2003
}

The views expressed herein are those of the authors and not necessarily those of the National Bureau of Economic Research.

(C)2003 by Robert Kaestner and Neeraj Kaushal. All rights reserved. Short sections of text, not to exceed two paragraphs, may be quoted without explicit permission provided that full credit, including (C) notice, is given to the source. 
Welfare Reform and Health Insurance Coverage of Low-Income Families

Robert Kaestner and Neeraj Kaushal

NBER Working Paper No. 10033

October 2003

JEL No. I18, I38

\title{
ABSTRACT
}

We study whether welfare reform adversely affected the health insurance coverage of low-educated single mothers and their children. Specifically, we investigate whether changes in the welfare caseload during the 1990s were associated with changes in Medicaid participation, private insurance coverage, and the number of uninsured among single mothers and their children. Estimates suggest that between 1996 and 1999, the 42 percent decrease in the welfare caseload was associated with the following changes in insurance coverage among low-educated, single mothers: a seven to nine percent decrease in Medicaid coverage; an increase in employer-sponsored, private insurance coverage of six percent; and a two to nine percent increase in the proportion uninsured. Among children of low-educated, single mothers, effects were somewhat smaller. Since welfare policy was responsible for only part (e.g., one-third) of the decline in the caseload, welfare reform per se had significantly smaller effects on the health insurance status of low-income families. However, we found limited evidence that changes in the caseload due to state and federal welfare policy had fewer adverse consequences on insurance status than changes in the caseload due to other factors. This implies even smaller effects of welfare reform.

\author{
Robert Kaestner \\ Institute of Government and Public Affairs \\ University of Illinois at Chicago \\ 815 W. Van Buren Street, Suite 525 \\ Chicago, IL 60607 \\ and NBER \\ kaestner@uic.edu \\ Neeraj Kaushal \\ School of Social Work \\ Columbia University \\ 622 West $113^{\text {th }}$ Street \\ New York, NY 10025
}




\section{Introduction}

The Personal Responsibility and Work Opportunity Reconciliation Act (PRWORA) eliminated entitlement to cash assistance, required recipients to meet new work requirements, and instituted lifetime time limits on participation. One of the main goals of the program was to move recipients of cash assistance (i.e., welfare), who are mostly women with children, off public assistance and into the workforce as quickly as possible. Many state welfare reform efforts that preceded PRWORA shared this emphasis on employment as a means to leaving public assistance. Partly as a consequence of these efforts, the number of welfare recipients dropped 62 percent between January 1993 and March 2001, from about 14.1 million recipients in 1993 to 5.4 million recipients in 2001.

A decline in the welfare caseload of this magnitude has the potential to reduce significantly the prevalence of health insurance among low-income families, particularly those headed by unmarried women. Health insurance coverage of these families may be adversely affected because those who leave, or are deterred from entering, the welfare program may find it difficult to obtain Medicaid coverage due to administrative hurdles, and because many of the jobs that low-skilled women typically obtain after leaving welfare do not offer private health insurance. This scenario is consistent with evidence from studies of former welfare recipients, which show that many women and children who left welfare are without insurance (Guyer 2000).

If welfare reform led to loss of health insurance coverage, it would most likely reduce low-income families' health care utilization and possibly adversely affect the health of persons in these families (Currie and Grogger 2002). Knowledge of such unintended consequences would almost certainly influence the debate over the efficacy of current welfare policy. In fact, the original Congressional deliberations over welfare reform led to bipartisan support to insure, through provisions in the legislation, that welfare reform did not affect health insurance coverage.

In sum, the effect of welfare reform on health insurance coverage is an important and timely public policy issue that is under-researched. In spite of the relatively sparse scientific literature on the subject, it is widely believed that welfare reform has adversely affected the health insurance coverage of low-income families. However, much of the information that is available on the issue has been produced by advocacy 
groups and is of questionable scientific value. Moreover, the few studies of this problem by social scientists have not reached a consensus on this issue underscoring the need for additional research.

In this article, we study whether welfare reform adversely affected the health insurance coverage of loweducated women and their children. Specifically, we obtain estimates of the effect of the welfare caseload and state and federal welfare reform policies on Medicaid participation, private insurance coverage, and the number of uninsured among low-income families. To obtain these estimates we use multivariate regression methods that control for the influence of the economy and other measured factors on health insurance coverage. To bolster the causal interpretation of our estimates, we use a pre- and post-test with a comparison group research design. For this procedure, we obtain regression estimates of the effect of the welfare caseload and welfare reform policy on insurance coverage for low-income families likely to be affected by welfare reform, and similar estimates for low-income families unlikely to be affected by welfare reform. The difference in these estimates is the effect of the welfare caseload and welfare reform policy on health insurance coverage of the affected group.

\section{Background and Literature Review}

It is widely believed that an unintended consequence of welfare reform was the loss of health insurance coverage among low-income families. This belief is based on several pieces of information: studies of welfare "leavers," which find that a substantial proportion of former welfare recipients are uninsured in the year after leaving welfare (Moffitt and Slade 1997; Guyer 2000; Garrett and Holahan 2000; Garrett and Hudman 2002); studies of the effect of welfare reform on Medicaid enrollment, which find a significant decline in Medicaid enrollment among low-income women and children after the implementation of welfare reform (Families USA Foundation 1999; Kronebusch 2001; Ku and Garrett 2000); and evidence that administrative hurdles limit enrollment in Medicaid for low-income families not receiving public assistance (Ellwood 1999). We take a more critical view of this evidence and argue that the widely held view that welfare reform resulted in a loss of health insurance is not well founded.

Consider the evidence from "leaver" studies. These studies cannot differentiate between women and children who left public assistance because of welfare reform, and those who left public assistance voluntarily- 
i.e., those who would have left public assistance even in the absence of reform. Recent evidence suggests that between one-tenth and one-third of the decline in welfare caseloads is a result of welfare reform (Blank 2002). Thus, only a portion of the families in "leaver" studies are relevant to the question of the effect of welfare reform on health insurance status. Since the motivation for leaving welfare is by definition different between the two groups - one was induced to leave by legislation and the other left voluntarily — this suggests that the circumstances surrounding, and the consequences of leaving, welfare may also be very different for these two groups. In addition, leaver studies fail to consider the experiences of those who were diverted from welfare because of changes in policy. In sum, "leaver" studies cannot in general identify the effect of welfare reform on health insurance.

In addition to "leaver" studies, the belief that welfare reform adversely affected health insurance coverage is supported by a few studies that show a steep decline in Medicaid coverage about the same time welfare reform was implemented. Probably the most widely cited of these is a study by Families USA Foundation (1999). This study has had a particularly powerful impact on public opinion and is cited by numerous groups advocating for changes in welfare policy. Ku and Garrett (2000) and Kronebusch (2001) also report that welfare reform was associated with a significant loss in Medicaid coverage among low-income families.

There are several problems with these studies. Two of these studies do not link the implementation of welfare reform to changes in Medicaid coverage as purported. Instead, these studies measure the change in Medicaid coverage for a group of low-income families between certain years (e.g., 1995 and 1997) during which time some welfare reform took place. This strategy ignores the fact that many states implemented welfare reform at different times, some prior to the years studied and some after the years studied. ${ }^{1}$ Another shortcoming of these studies is their failure to examine changes in private insurance coverage and the number of uninsured associated with welfare reform. This is surprising, because research has demonstrated that welfare reform significantly increased the employment rate of low-income women (Blank 2002; Kaushal and Kaestner

\footnotetext{
${ }^{1}$ For example, according to data in the Families USA Foundation (1999) report, Medicaid coverage declined in California by approximately 30 percent between 1995 and 1997 . However, during this period there was no welfare reform in California. California had an AFDC waiver that was implemented prior to 1995 and California did not implement federally mandated reform until 1998.
} 
2001; CEA 2000). As a result, it is possible that a greater portion of these women will be covered by private insurance and this increase in private insurance could explain part of the decline in Medicaid coverage. Finally, these studies do not adequately control for changes in Medicaid and the number of uninsured that are unrelated to welfare reform. ${ }^{2}$

Is it possible that welfare reform increased the number of low-income women and children without health insurance? The answer is clearly yes. There are a variety of ways that welfare reform may have affected health insurance coverage. Women who leave welfare are eligible for transitional Medicaid benefits, but these benefits end after one year, and administrative hurdles may cause take-up rates for transitional benefits to be low among welfare leavers. There are no transitional benefits for women who were deterred from entry into AFDC/TANF by welfare reform, and since many of these women are working, their earnings may push them over the very low Medicaid income-eligibility thresholds for adults. Offsetting these adverse effects is the possibility that some low-income women induced to work by welfare reform will have access to employerprovided health insurance. However, the relatively low-paying jobs that these women usually obtain do not frequently provide subsidized benefits. As a result, we would expect the number of uninsured to rise after welfare reform.

Is there existing evidence that establishes this fact? The answer appears to be no. Therefore, additional research is warranted. Our study makes several contributions. First, we examine both "exit" and "entry" effects of welfare reform on health insurance coverage. Second, we explicitly link both state and federal welfare reform to changes in insurance coverage by examining the relationship between changes in the welfare caseload and the timing of welfare reform policies to changes in insurance status. Finally, we use a research design that addresses in a more complete way than past research the possibility that unmeasured trends may confound estimates of the effect of welfare reform on health insurance status.

2 This problem may be particularly severe in Chavkin et al. (2000) because they do not limit their sample to those most likely affected by welfare reform-i.e., low-income families. For example, including the unemployment rate controls for the effect of economic conditions on the health insurance coverage of a heterogeneous group of persons and not the group of interest. This may bias estimates. 


\section{Research Design and Statistical Methods}

The hypothesis underlying our empirical analysis is straightforward: welfare reform reduced the number of low-income women and children on public assistance and as a result may have increased the number of uninsured persons in these groups because of declines in Medicaid coverage that were not fully offset by increases in private insurance coverage. Therefore, the most straightforward way to assess the effect of welfare reform on the insurance status of low-income families is to obtain estimates of the association between the welfare caseload and insurance coverage. This is the strategy pursued by Currie and Grogger (2002) with regard to Medicaid for the pre-PRWORA period. Accordingly, we begin by estimating the following model:

$$
\begin{aligned}
& \text { Ins }_{\mathrm{ijt}}=\beta_{\mathrm{j}}+\delta_{\mathrm{t}}+\gamma \text { Caseload }_{\mathrm{jt}}+\mathrm{Z}_{\mathrm{jt}} \Phi+\mathrm{X}_{\mathrm{ijt}} \Gamma+\mathrm{u}_{\mathrm{ijt}} \\
& \mathrm{i}=1, \ldots, \mathrm{N} \text { (persons) } \\
& \mathrm{j}=1, \ldots, 51 \text { (states) } \\
& \mathrm{t}=1992, \ldots, 1999 \text { (years) }
\end{aligned}
$$

In equation (1), health insurance status (e.g., Medicaid) of person $\mathrm{i}$ in state $\mathrm{j}$ and year $\mathrm{t}$ is a function of the welfare caseload in state $\mathrm{j}$ and year $\mathrm{t}$; time-varying state characteristics $\left(Z_{j t}\right)$ such as the Medicaid income eligibility threshold, the unemployment rate, and per-capita income; individual characteristics $\left(X_{\mathrm{ijt}}\right)$ such as age, race and family composition; state fixed effects $\left(\beta_{j}\right)$; and year effects $\left(\delta_{t}\right)$. Estimates of equation (1) can be obtained using a variety of statistical methods including ordinary least squares - the method we have selected.

One disadvantage of equation (1) is that it assumes that welfare reform was responsible for all of the change in the welfare caseload. In fact, evidence suggests that most of the change in the caseload was not due to policy, particularly prior to the implementation of PRWORA in 1996 (Blank 2002). Therefore, estimates of the association between the welfare caseload and insurance status represent upper bound estimates of the effect of welfare reform. For example, if welfare reform was responsible for one-third of the decline in the caseload, then estimates from equation (1) should be divided by three to derive the effect of welfare reform. However, it is possible that those who leave welfare because of government policy may have different experiences than those 
who leave for other reasons such as robust economic growth. If so, then it is not appropriate to simply apportion the effect the caseload to estimate the effect of welfare reform.

A preferable model would be one in which we allowed the effect of the welfare caseload on insurance to differ by the cause of the change in the caseload, as in the following:

(2) $\operatorname{Ins}_{\mathrm{ijt}}=\beta_{\mathrm{j}}+\delta_{\mathrm{t}}+\gamma_{1} \operatorname{Case}(\text { Policy })_{\mathrm{jt}}+\gamma_{2} \operatorname{Case}(\operatorname{Re} \text { sidual })_{\mathrm{jt}}+\mathrm{Z}_{\mathrm{jt}} \Phi+\mathrm{X}_{\mathrm{ijt}} \Gamma+\mathrm{u}_{\mathrm{ijt}}$

In equation (2), the variables Case(Policy) and Case(Residual) are the portions of the welfare caseload related to welfare policy and other factors, respectively. The coefficient on Case(Policy) provides an estimate of the effect of welfare reform on insurance status. The two caseload variables in equation (2) are derived from the following:

(3) Caseload $_{\mathrm{jt}}=\alpha_{\mathrm{j}}+\rho_{\mathrm{t}}+\lambda_{1} \mathrm{TANF}_{\mathrm{jt}}+\lambda_{2}(\mathrm{AFDC}$ Waiver $)+\mathrm{Z}_{\mathrm{jt}} \Psi+\mathrm{v}_{\mathrm{jt}}$

(4) Case(Policy) ${ }_{\mathrm{jt}}=\lambda_{1}(\mathrm{TANF})_{\mathrm{jt}}+\lambda_{2}(\text { AFDC Waiver })_{\mathrm{jt}}$

(5) Case $(\text { Re sidual })_{j t}=$ Caseload $_{j t}-$ Case $(\text { Policy })_{j t}$

Equation (3) is the structural model determining the welfare caseload, which we assume depends on welfare policies, AFDC waivers and TANF (Temporary Assistance to Needy Families), and other factors. Equations (4) and (5) simply decompose the caseload into that due to policy [Case(Policy)] and that due to other factors [Case(Residual)]. To estimate equation (2) requires that we first estimate equation (3) and then construct the variables of interest. However, obtaining estimates of the effect of welfare policy on the welfare caseload has been a controversial area of research (Blank 2002). The fundamental problem has been that it is difficult to distinguish the effect of policy from the effect of other factors such as the unemployment rate. ${ }^{3}$ If equation (3) is incorrectly specified, then using estimates from it to construct the variables Case(Policy) and Case(residual) will result in biased estimates of equation (2). In effect, any specification error in equation (3) will be transmitted to equation (2).

We can avoid this problem by substituting equations (4) and (5) into equation (2) and estimating the following model: 


$$
\begin{aligned}
\text { Ins }_{\mathrm{ijt}}= & \beta_{\mathrm{j}}+\delta_{\mathrm{t}}+\left(\gamma_{1}-\gamma_{2}\right) \lambda_{1}(\mathrm{TANF})_{\mathrm{jt}}+\left(\gamma_{1}-\gamma_{2}\right) \lambda_{2}\left(\text { AFDC Waiver }_{\mathrm{jt}}+\right. \\
& \gamma_{2} \text { Caseload }_{\mathrm{jt}}+\mathrm{Z}_{\mathrm{jt}} \Phi+\mathrm{X}_{\mathrm{ijt}} \Gamma+\mathrm{u}_{\mathrm{ijt}}
\end{aligned}
$$

Equation (6) allows us to test whether the effect of changes in the caseload caused by welfare policy $\left(\gamma_{1}\right)$ differs from the effect of changes in the caseload due to other factors $\left(\gamma_{2}\right)$, but it avoids having to estimate equation (3). The coefficients on the welfare policy variables (TANF and AFDC Waivers) measure the difference between the effect of the caseload due to policy and the effect of the caseload due to other factors. Note that $\lambda_{1}$ and $\lambda_{2}$, the effects of policy on the welfare caseload, are expected to be negative, so the coefficients on the policy variables will have the opposite sign of the true difference. Another advantage of equation (6) is that it allows changes in the caseload associated with TANF and AFDC waivers to have different effects on insurance status.

To a large extent, equations (1) and (6) address the fundamental identification problem associated with this analysis, which is to isolate the effect of changes in the welfare caseload or changes in government policy from other determinants of women's, or children's, health insurance coverage that vary over time, across states and over time within states. The primary remaining weakness is that there may be omitted variables that vary by state and year that affect health insurance coverage of persons in low-income families and that are correlated with the welfare caseload or government policy.

To address this problem, we rely on a comparison group approach. To implement this approach, we estimate equations (1) and (6) for two groups: those likely to participate in the cash assistance program and therefore likely to be affected by welfare reform, and those unlikely to participate in the cash assistance program and therefore unlikely to be affected by welfare reform. We refer to the former as the target group and the latter as the comparison group. A critical assumption underlying this strategy is that in the absence of welfare reform (e.g., changes in the welfare caseload) changes in health insurance status would be similar between the target group - for example, low-educated unmarried women, and the comparison group.

The counterpart of equation (1) for the comparison group is the following:

\footnotetext{
${ }^{3}$ Our task would be particularly difficult since we would need to estimate state-specific effects of policy so that the predicted caseload variables would have state-time variation. Restricting the effect of policy to be constant across states would leave no state-time variation and only limited time variation in the predicted caseload variable.
} 
(7) $\operatorname{Ins}_{\mathrm{ijt}}=\widetilde{\beta}_{\mathrm{j}}+\widetilde{\delta}_{\mathrm{t}}+\widetilde{\gamma}$ Caseload $_{\mathrm{jt}}+\mathrm{Z}_{\mathrm{jt}} \widetilde{\Phi}+\mathrm{X}_{\mathrm{ijt}} \widetilde{\Gamma}+\mathrm{e}_{\mathrm{ijt}}$

The key point to note about equation (7) is that the coefficient on the welfare caseload variable, $\widetilde{\gamma}$, should be zero since this group is not at risk of welfare receipt and changes in the welfare caseload should not affect their insurance status. A non-zero estimate of this parameter indicates that there are omitted variables that affect health insurance that are correlated with the welfare caseload. Therefore, we can subtract this effect from the corresponding estimate $(\gamma)$ in equation (1) to obtain an estimate of the effect of the caseload on health insurance that controls for these omitted variables. This approach is commonly referred to as a difference-in-differences (DD) and estimates can be obtained directly by combining equations (1) and (7):

$$
\begin{gathered}
\text { Ins }_{\mathrm{ijt}}=\widetilde{\alpha}+(\alpha-\widetilde{\alpha}) \operatorname{Treat}_{\mathrm{i}}+\widetilde{\beta}_{\mathrm{j}}+\left(\beta_{\mathrm{j}}-\widetilde{\beta}_{\mathrm{j}}\right) \text { Treat }_{\mathrm{i}}+\widetilde{\delta}_{\mathrm{t}}+\left(\delta_{\mathrm{t}}-\widetilde{\delta}_{\mathrm{t}}\right) \text { Treat }_{\mathrm{i}}+\widetilde{\gamma} \text { Caseload }_{\mathrm{jt}}+ \\
(\gamma-\widetilde{\gamma})\left(\text { Caseload }_{\mathrm{jt}} \times \text { Treat }_{\mathrm{i}}\right)+\mathrm{Z}_{\mathrm{jt}} \widetilde{\Phi}+\left(\mathrm{Z}_{\mathrm{jt}} \times \text { Treat }_{\mathrm{i}}\right)(\Phi-\widetilde{\Phi})+\mathrm{X}_{\mathrm{ijt}} \widetilde{\Gamma}+ \\
\left(\mathrm{X}_{\mathrm{ijt}} \mathrm{x} \text { Treat }_{\mathrm{i}}\right)(\Gamma-\widetilde{\Gamma})+\mathrm{v}_{\mathrm{ijt}}
\end{gathered}
$$

The only new variable in equation (8) is "Treat," which is a dichotomous variable equal to one if the person is in the target group and equal to zero if the person is in the comparison group. The DD estimate of the effect of the welfare caseload is $\gamma-\tilde{\gamma}$. Equation (8) is the least restrictive specification possible. In fact, although not reflected in equation (8), we include dummy variables for each state-year combination instead of the caseload variable itself. ${ }^{4}$ The only identifying restriction is that in the absence of welfare reform, unmeasured state-year influences on health insurance status would affect the target and comparison group equally. If this assumption is valid, then the parameter $\tilde{\gamma}$ captures the influence of these unmeasured determinants that are correlated with the welfare caseload.

Clearly, the choice of target and comparison groups is crucial to the success of the difference-indifferences design. Identifying a target group is relatively straightforward. Welfare reform was intended to decrease the welfare caseload, which consists primarily of low-educated, single mothers. Accordingly, we define our target group to be single mothers with 12 or fewer years of education, and the children of these women. $^{5}$ The comparison group is more difficult. We choose two groups: low-educated (education $\leq 12$

\footnotetext{
${ }^{4}$ Statistical tests rejected more restrictive specifications of equation (8).

${ }^{5}$ It is possible that welfare reform affected fertility and marriage, so selecting the sample on these characteristics may result in changes in sample composition. Based on existing evidence, however, we believe the bias due to sample selection will
} 
years), single women without children; and low-educated (education $\leq 12$ years), married mothers. Obviously, the first comparison group is not relevant for the analysis of the effect of welfare reform on children's health insurance status.

A cursory way to assess the adequacy of the comparison groups is to compare the mean rates of insurance coverage of the target group to the mean rates of insurance coverage of the comparison groups. Means of roughly similar magnitudes suggest that the insurance status of the two groups may be influenced by similar factors. These figures are shown in Table 1. We focus on the initial year of our analysis, 1992, which predated most welfare reform legislation.

The figures in Table 1 show that the target and comparison groups have rates of employer-sponsored insurance in the respondent's own name and rates of uninsured that are quite similar, but that the proportion of each group covered by Medicaid and private insurance is noticeably different. As expected, women and children in the target group have much higher rates of Medicaid coverage and much lower rates of private insurance coverage. These disparities reflect the higher rates of labor force participation among families (including spouse) in the comparison group and the higher rates of welfare participation among families in the target group. Welfare participation and Medicaid coverage are substitutes for employment (and marriage) and private insurance coverage. The key question for our analysis is whether the two groups would have similar insurance coverage in the absence of a cash assistance program.

The answer appears to be yes. To see why, note that approximately 50 percent of low-educated, single mothers are on public assistance. ${ }^{6}$ Thus, figures in Table 1 suggest that 31 percent of the remaining women in this group are covered by private insurance. This implies that approximately 62 percent of the women in the target group who are not on public assistance are covered by private health insurance. This 62 percent figure is quite similar to the percentage of women covered by private insurance in the two comparison groups. While these calculations are rough, and ignore selection effects that would likely reduce the 62 percent figure for the target group, they make the point that the comparison groups selected are reasonable in the sense that their insurance coverage appears to be similar to that of target group members who are not on public assistance. This 
is exactly the group that is relevant to our analysis since the purpose of our analysis is to examine what happens to insurance coverage when women leave public assistance because of welfare reform.

The only insurance state for which there is not an adequate comparison group is Medicaid for adult women. Women in the comparison groups are for the most part ineligible for Medicaid and therefore there is little likelihood of observing significant changes in Medicaid coverage that are correlated with welfare reform. ${ }^{7}$ Thus, for Medicaid coverage of adult women, the comparison group approach is not very useful, and therefore we will not rely on it. The story is somewhat different for children of married mothers - the comparison group for children of single mothers. Expansions in Medicaid eligibility affected many children in this category, as evidenced by the significant increase in Medicaid coverage of this group between 1992 and 1996 (see Table 2). So for children's Medicaid coverage, the comparison group approach is appropriate.

\section{Data}

Our primary data source is the March Current Population Survey (CPS) for the years 1993 to 2000, which provides information on the health insurance status for the years 1992-1999. It was during this period that nearly all of the state and federal welfare reform occurred. We focus on low-educated women and their children because these are the target group of welfare reform. Specifically, we define the target group to be unmarried mothers between the ages of 18 and 44 who have 12 or fewer years of education. We limit the sample of children of these women to those between the ages of 0-14 years. As previously noted, we use two comparison groups in the analysis of women's insurance: low-educated (education $\leq 12$ years), single women without children; and low-educated (education $\leq 12$ years), married mothers. Both comparison groups are restricted to women between the ages of 18 and 44. In the analysis of children's insurance, we use children of married mothers with 12 or fewer years of education.

\footnotetext{
${ }^{6}$ Data in the CPS indicate that 43 percent of this group received AFDC income in the past year.

${ }^{7}$ A small portion of women in the two comparison groups may be eligible for Medicaid, or other state-funded health insurance. For example, married women will be eligible for AFDC and Medicaid through the AFDC-UP program. Similarly, some states provide cash assistance to single adults (general assistance programs) and provide public health insurance coverage. Approximately five percent of women in the comparison groups reported receiving AFDC benefits in the past year.
} 
The CPS contains most of the data necessary to complete our analysis. Most importantly, the CPS provides information on the insurance status in the last year including whether the person was covered by Medicaid, private insurance, employer-sponsored insurance in her own name, or some other type of public insurance. ${ }^{8}$ We define four categories of insurance: private insurance, which includes employer-sponsored and other group or individual private insurance plans; employer-sponsored insurance in respondent's own name; public insurance, which includes Medicaid, SCHIP and other publicly provided insurance; and uninsured. ${ }^{9}$ One limitation of the CPS is that Medicaid coverage is under-reported relative to administrative data. Whether or not the under-reporting is systematically related to welfare reform, however, is unknown. Many analyses have used the CPS to study the effect of public policies such as the Medicaid expansions on health insurance coverage, and some have adjusted for the under-reporting of Medicaid (e.g., Dubay and Kenney 1996). Taking account of the under-reporting does not appear to make a significant difference.

The CPS also contains basic demographic information that can be used to construct control variables and that allow us to link children to their mothers. As noted, we define our target and comparison groups on the basis of education and marital status. Other personal characteristics included in the model include: family size, “other” family income, mother's age, mother's race, total number of kids and number of young kids in the family. ${ }^{10}$

Finally, the CPS provides respondents' state of residence, which allows us to append state-level information. We use the following: state and federal welfare policy; annual welfare caseload, as measured by average number of families on welfare per month; Medicaid income eligibility threshold; current unemployment rate and one-year lag; and real per-capita income. ${ }^{11}$ For women, state Medicaid eligibility variables are defined on the basis of Medicaid eligibility of pregnant women; we use the following categories: 0 to 133 percent of federal poverty line, 134 to 199 percent of federal poverty line, and above 200 percent of the federal poverty line. For children, Medicaid eligibility is specific to a child's age and is the higher of the Medicaid or SCHIP

\footnotetext{
${ }^{8}$ There is some question as to whether respondents are referring to last year or the current period when providing information about health insurance coverage. We assume that it refers to the last year as specified in the question and accordingly, we match the welfare caseload information to the last calendar year.

${ }^{9}$ We exclude persons covered by CHAMPUS or Indian Health Service from both the private and public insurance categories.

${ }^{10}$ Other family income $=$ family earnings - woman's earnings + interest income + dividends + rental income.

${ }^{11}$ Aaron Yellowitz graciously provided us with the Medicaid income eligibility data.
} 
income eligibility threshold; we use the following categories: 0 to 49 percent of the federal poverty line; 50 to 100 of federal poverty line; 101 to 133 percent of the federal poverty line; 134 to 199 percent of the federal poverty line; and above 200 percent of the federal poverty line.

The annual welfare caseload data is taken from the Administration for Children and Families and refers to the average number of families receiving benefits in the year. We measure the caseload as the natural logarithm of the caseload. ${ }^{12}$ The data on welfare policies is drawn from Assistant Secretary for Planning and Evaluation of the Department of Health and Human Services, as well as from the Urban Institute (www.urban.org/content/Research/NewFederalism/Data/StateDatabase/StateDatabase.htm) and the State Documentation Project of the Center on Budget and Policy Priorities (www.cbpp.org). We follow the earlier literature on the effects of welfare reform and use dummy variables for whether a state had implemented an AFDC waiver or TANF. We set the waiver variable to zero when TANF is implemented. In cases where the state implemented reform during the year, we use the fraction of the year that the policy was in place. All state level variables are merged to the CPS in the year prior to the survey year. So the 1998 welfare caseload is merged to the 1999 CPS survey.

\section{Results}

\section{Descriptive Analysis}

Table 1 presents sample proportions of health insurance coverage. In 1992, half of all single mothers, the group most likely to be affected by welfare reform, received Medicaid and around 30 percent of women in this group were covered by private insurance, leaving the remaining 20 percent or so uninsured. ${ }^{13}$ Between 1992 and 1996, during which a number of states implemented welfare reform under AFDC waivers, the proportion of single mothers covered by Medicaid fell around five percentage points and the proportion covered by private insurance increased approximately two percentage points; the proportion uninsured rose by about five percentage points. This general trend in the insurance coverage of this group became more marked after 1996,

\footnotetext{
${ }^{12}$ All models were also estimated using the "welfare rate", which is the caseload divided by the population. Results using this alternative measure were similar to those presented below and are therefore not reported.

${ }^{13}$ Row percentages do not add to 100 because some respondents indicate coverage by more than one type of insurance.
} 
when federal welfare reform was enacted; Medicaid coverage declined, and private insurance increased, even more rapidly than in the earlier period. However, the rate of uninsured grew more slowly.

Among the children of single mothers, a slightly different story emerges. Between 1992 and 1996 there is a slight increase in Medicaid coverage and little change in the proportion covered by private insurance and the proportion uninsured. After 1996, the trends for children of single mothers are similar to that of their mothers: Medicaid coverage declines, private insurance coverage increases and the proportion uninsured grows modestly.

The critical question is how much of these observed changes are due to welfare reform and how much are due to other factors? Some insight into this question can be gleaned by examining changes in health insurance coverage of groups unaffected by welfare reform. Doing so reveals that for women in the two comparison groups, there has been little change in insurance coverage during this period. This suggests that most of the changes in insurance coverage of the target group are due to welfare reform. Once more, a slightly different story emerges for children; between 1992 and 1996, Medicaid coverage increased, private insurance coverage decreased, and the proportion uninsured increased among children living with two parents. After 1996, there was little change in the insurance coverage of this group. This suggests that some of the changes in insurance coverage during the 1992 to 1996 period may have been due to other factors besides welfare reform. One important change during this period was the expansion of income eligibility thresholds in the Medicaid program.

In sum, the descriptive data in Table 1 suggests that welfare reform had an effect on the health insurance coverage of low-income families. These data also suggest that other factors may have influenced health insurance coverage and that in order to identify the effect of welfare reform it will be necessary to control for these influences in the statistical analysis. To investigate these issues, we now turn to the multivariate analysis.

\section{Multivariate Analysis-Women}

To review, our research strategy involves obtaining estimates of equations (1) and (6) for the target and comparison groups, and difference-in-differences estimates. All estimates are obtained by ordinary least squares and standard errors of the estimates are calculated under the assumption that observations from the same state are not independent (Bertrand et al. 2002). 
Table 2 presents estimates of the effect of the welfare caseload and welfare policy on the insurance status of low-educated single mothers. Row one presents estimates of equation (1) and row two presents estimates of equation (6). Estimates of the effects of Medicaid eligibility and unemployment are also presented, and these estimates come from the same model as estimates in row two. Estimates in row one indicate that decreases in the welfare caseload are associated with a decrease in Medicaid coverage, an increase in employersponsored insurance coverage, and an increase in the proportion uninsured. Only the effect of the welfare caseload on Medicaid is statistically significant. Between 1996 and 1999 the natural logarithm of the caseload decreased by approximately $0.5 \log$ points, or 42 percent (www.acf.dhhs.gov), so the estimates in row one indicate that changes in the caseload during this period resulted in the following: a 4.0 percentage point decrease in Medicaid coverage, which represents only 40 percent of the actual decline during this period; a 2.0 percentage point increase in employer-sponsored insurance; and a 1.6 percentage point increase in the proportion uninsured.

With regard to Medicaid income eligibility thresholds and unemployment, there are only a few statistically significant effects. Unemployment, specifically, the one-year lag, is negatively associated with employer-sponsored insurance coverage; a one percentage point increase in the lagged unemployment rate is associated with a 1.3 percentage point decrease in the proportion of single mothers covered by employersponsored insurance. The only significant (marginally) estimate associated with the Medicaid dummy variables is for employer-sponsored insurance; coverage is lower in states with Medicaid income eligibility thresholds for pregnant women of 185 percent or more of the federal poverty level. ${ }^{14}$

Row two presents estimate from equation (6), which include the welfare policy variables in addition to the welfare caseload. The coefficients on the policy variables measure the difference between the effect of changes in the caseload due to policy $\left(\gamma_{1}\right)$ and the effect of changes in the caseload due to other factors $\left(\gamma_{2}\right)$. Specifically, the coefficient on TANF measures $\left(\gamma_{1}-\gamma_{2}\right) \lambda_{1}$; and the coefficient on AFDC waivers measures $\left(\gamma_{1}-\gamma_{2}\right) \lambda_{1}$. The parameters $\lambda_{1}$ and $\lambda_{2}$ are the effect of TANF and AFDC waivers on the log caseload, respectively. Evidence shows that these parameters are negative and in the range of -0.1 to -0.3 ; AFDC waivers

\footnotetext{
${ }^{14}$ We also estimated models that included the Medicaid income eligibility levels for children less than six years of age to see whether there may be some spillover effects due to family coverage. None of the Medicaid eligibility levels associated for children had a significant effect on mother's insurance status.
} 
and TANF reduced the welfare caseload by between 10 and 30 percent (Blank 2002). Therefore, a positive (negative) coefficient on the policy variables implies that the effect of changes in the caseload due to policy is smaller (larger) than the effect of changes in the caseload due to other factors.

Estimates in row two for Medicaid indicate that the coefficients on TANF and AFDC waivers are positive, which suggests that the effect of changes in the welfare caseload due to policy have a smaller (less positive) effect on Medicaid than changes in the caseload due to other reasons. Neither of the estimates associated with the policy variables is statistically significant. To obtain an estimates of $\gamma_{1}$, we assume that $\lambda_{1}=\lambda_{2}=-0.3$, which is at the high range of estimates of the effect of welfare reform policy on the log caseload, and use the coefficient on the caseload as an estimate of $\gamma_{2}$. The calculated estimates of $\gamma_{1}$ for TANF and AFDC waivers are presented in Table 2. These estimates suggest that decreases in the caseload due to TANF were associated with an increase in Medicaid receipt, and that decreases in the caseload due to AFDC waivers were associated with a decrease in Medicaid receipt. ${ }^{15}$

In the case of employer-sponsored insurance, the coefficients on TANF and AFDC waivers are positive, which implies that changes in the caseload due to policy had a larger negative effect on employer-sponsored insurance than did changes in the caseload due to other factors. Here too the estimates are not statistically significant. Finally, for the uninsured dependent variable, the coefficients on the policy variables are negative and the estimate associated with AFDC waivers is statistically significant. Thus, changes in the caseload due to policy had a less negative effect on the proportion uninsured than did changes in the caseload due to other factors. In fact, the implied estimates of $\gamma_{1}$ are positive- suggesting that state and federal welfare reform reduced the number of uninsured.

In sum, the addition of the welfare policy variables to the model had little effect from a statistical point of view. Nearly all the estimates associated with the policy variables are statistically insignificant, and the estimates of the effect of the welfare caseload itself were not greatly affected by the addition of the policy

${ }^{15}$ In the case of TANF, the calculation is as follows: $\gamma_{1}=\frac{0.027}{-0.2}+0.085=-0.05$. For AFDC waivers: $\gamma_{1}=\frac{0.015}{-0.2}+0.085=0.01$ 
variables. This suggests that changes in the caseload due to policy had the same effect on insurance status as changes in the caseload due to other reasons. Estimates in row one of Table 2 suggest that the 42 percent decrease in the welfare caseload between 1996 and 1999 resulted in the following insurance status changes among low-educated single mothers: a nine percent decrease in Medicaid coverage; a six percent increase in employer-sponsored insurance coverage; and a six percent increase in the proportion uninsured. If we interpret the insignificant coefficients on the policy variables as evidence that changes in the caseload due to policy had the same effect as changes in the caseload due to other factors, and assume that welfare policy was responsible for one-third of the decline in the caseload, then between 1996 and 1999, welfare reform per se was associated with a three percent decrease in Medicaid coverage; a two percent increase in employer-sponsored insurance coverage; and a two percent increase in the proportion uninsured.

Although not statistically significant, the coefficients on the policy variables indicated that decreases in the caseload associated with welfare policies had a smaller adverse impact on Medicaid and the proportion uninsured, and a larger beneficial effect on employer-sponsored insurance, than did changes in the caseload due to other reasons. In fact, calculations suggest that changes in the caseload due to welfare policy resulted in a decrease in the proportion uninsured, although given the statistical insignificance of the underlying estimates and the somewhat subjective assumption as to the effect of policy on the caseload used in these calculations, we do not place too much weight on this evidence.

We now turn to the difference-in-differences estimates, which address the possibility that estimates in Table 2 may be confounded by unmeasured, state-specific effects. Table 3 presents the difference-in-differences (DD) estimates related to equation (1), which are in row one, and equation (6), which are in row two. ${ }^{16}$ For each insurance category, there are DD estimates corresponding to two comparison groups - married women with children and single women with no children. In general, the DD estimates in row one are very similar to the corresponding estimates in Table 2. Indeed, as estimates in Appendix Table 1 show, the welfare caseload is never significantly related to the insurance status of either of the comparison groups. DD estimates in row one

\footnotetext{
${ }^{16}$ We show the estimates of the effect of the welfare caseload on Medicaid for the sake of completeness, but, as previously noted, the comparison groups that we use are not adequate for this outcome because most members of the comparison groups are not eligible for Medicaid and any changes in Medicaid are likely to be small and idiosyncratic. Therefore, we
} 
indicate that the decline in the welfare caseload in the late $1990 \mathrm{~s}(0.5 \log$ points $)$ was associated with the following changes in the health insurance status of low-educated, single mothers: between a 3.1 to 4.0 percentage-point (seven and eight percent) decrease in Medicaid coverage; a 2.5 percentage-point (nine percent) increase in employer-sponsored insurance coverage; and between a 0.5 and 2.3 percentage-point (two to nine percent) increase in the proportion uninsured. The magnitudes of the effects are similar to those of estimates in Table 2, but not all of the DD estimates are statistically significant. However, most approach standard thresholds of statistical significance.

Estimates of the effect of the welfare caseload in row two are very similar to those in row one. In addition, estimates associated with the welfare reform policy variables in row two are not statistically significant. This suggests that there is no difference between the effect on insurance status of changes in the welfare caseload due to policy and the effect of changes in the welfare caseload due to other factors. Thus, the effects of welfare reform per se would be approximately one-third the size of the effects of the caseload, assuming that welfare reform was responsible for one-third of the change in the caseload. But here too, the signs of the coefficients on the policy variables suggest that changes in the caseload due to welfare reform had less adverse consequences. Calculated estimates of $\gamma_{1}$ in Table 3 indicate that decreases in the welfare caseload due to TANF and AFDC waivers were associated with smaller declines in Medicaid, larger increases in employer-sponsored insurance coverage, and smaller increases in the proportion uninsured, than were decreases in the caseload due to other reasons.

\section{Multivariate Analysis-Children}

We also investigated the effect of welfare reform and changes in the welfare caseload on the insurance status of children. The target group is children living with single mothers, and the comparison group is children living with married mothers. Our empirical strategy is the same as that used for adults and estimates are presented in Table 4, which has the same format as previous tables.

would not expect any variable, including the welfare caseload, to be correlated with the Medicaid coverage of this group. Estimates in Appendix Table 1 support this statement. 
Estimates in row one obtained using the sample of children in the target group indicate that decreases in the welfare caseload were associated with a significant decrease in Medicaid coverage, a significant increase in private coverage, and an insignificant increase in the proportion uninsured. To put these estimates in perspective, we again use the actual change in the caseload between 1996 and 1999 of $0.5 \log$ points (42 percent) to predict the changes in insurance status implied by the estimates. During this period, decreases in the caseload were associated with: a 3.1 percentage point (five percent) decrease in Medicaid coverage; a 2.4 percentage point (nine percent) increase in private insurance coverage; and a 1.2 percentage point (seven percent) increase in the proportion uninsured. DD estimates in row one are not statistically significant and suggest that decreases in the welfare caseload in the late 1990s were associated with a 1.7 percentage-point (three percent) decrease in Medicaid coverage, and 1.9 percentage point (11 percent) increase in the proportion uninsured with no change in private insurance coverage.

Row two presents the estimates of equation (6), which includes the welfare policy variables. The estimates associated with the welfare caseload in row two are very similar to those in row one. As for the policy variables, the coefficients on TANF and AFDC waivers are not statistically significant. So again, from a statistical point of view, the evidence in Table 4 suggests that changes in the welfare caseload due to policy had the same effect on the insurance status of children in low-income families as did changes in the welfare caseload due to other factors. Therefore, the effect of welfare reform on low-income children's insurance status would be significantly less, for example one-third the size, than the estimates associated with changes in the caseload. In all cases, however, the coefficients on the policy variables imply that changes in the caseload due to policy had less adverse consequences than did changes in the caseload due to other factors.

Other estimates of note in Table 4 are those pertaining to Medicaid income eligibility. These estimates suggest that expansions in Medicaid income eligibility thresholds were associated with a significant increase in Medicaid participation and a significant decrease in the proportion of uninsured children. There is little evidence that the Medicaid expansions resulted in a decline in private insurance coverage, contrary to some of the earlier literature in this area (Cutler and Gruber 1996). 


\section{Conclusions}

There is a widespread belief that an unintended consequence of welfare reform was loss of health insurance coverage among low-income families. This belief is supported by findings from "leaver" studies, which show that a significant number, perhaps 40 to 50 percent, of women and children who leave welfare are uninsured in the year after leaving welfare, and descriptive statistics from national data sources that show a significant decrease in Medicaid enrollment during the period of welfare reform. Moreover, the low rates of employer-sponsored insurance on jobs typically obtained by low-educated women, and the administrative hurdles associated with Medicaid enrollment, are consistent with the above belief. In this study, we investigated the empirical evidence to substantiate this belief.

Results from our study indicate that changes in the welfare caseload were associated with an increase in the proportion of low-educated women and their children who are without health insurance. However, the increase in the proportion uninsured is significantly less than that implied by "leaver" studies and approximately half of the actual decrease in Medicaid coverage. Estimates from our analysis suggest that the 42 percent decrease in the caseload between 1996 and 1999 were associated with the following changes in the insurance status of low-educated single mothers:

- a decrease in Medicaid participation of between three and four percentage points (between seven and nine percent);

- an increase in employer-sponsored insurance coverage of two percentage points (six percent);

- and an increase in the proportion uninsured of between 0.5 and 2.5 percentage points (two to nine percent).

For children in these families, the decline in the caseload between 1996 and 1999 was associated with the following:

- a decrease in Medicaid participation of between two to three percentage points (three to five percent);

- an increase in private insurance coverage of between zero and two percentage points (zero to nine percent); 
- and an increase in the proportion uninsured of between one and two percentage points (six and eleven percent).

A few points are worth noting. First, the increase in the proportion uninsured is less than the decline in Medicaid coverage; there is clear evidence that changes in the caseload and the resulting greater work effort of low-educated single mothers resulted in some increase in employer-sponsored coverage. Second, the increase in the proportion of low-educated, single mothers without health insurance is less than that implied by "leaver" studies. To see why, note that between 1996 and 1999, the proportion of low-educated single mothers receiving cash assistance in our sample decreased by 13.6 percentage points (40\%). If 40 percent of these women were uninsured, as suggested by "leaver" studies, the proportion of all low-educated, single mothers that are uninsured would have increased by $5.4(0.4 \times 13.6)$ percentage points. Our estimates suggest that it increased by between 0.5 to 2.5 percentage points, which is only 10 to 50 percent of the increase in uninsured implied by "leaver" studies. One possible reason for the difference between estimates is that "leaver" studies ignore entry effects; there may be significant heterogeneity in the health insurance coverage of women deterred from entering welfare and those induced to leave welfare.

We also obtained estimates of the effect of changes in the caseload due to state and federal welfare reform policy on the health insurance status of low-income families. On the one hand, these estimates indicated that changes in the caseload due to welfare policy had the same effect on insurance status as did changes in caseload due to other factors. This implies that the effect of welfare reform on insurance status was about one third the size of the effects listed above, assuming that welfare policy was responsible for one-third of the decline in the caseload. On the other hand, these estimates suggest, albeit with significant qualification, that decreases in the caseload caused by government policy had less adverse effects on health insurance coverage than did decreases in the caseload due to other factors. This is a reasonable result. Women induced to leave, or not enter, welfare because of government policy may be much more likely to take advantage of transitional Medicaid benefits and to find jobs that provide health insurance than women induced to leave the program because of a strong economy. The latter women may have better labor market opportunities and better long range economic prospects that include obtaining private health insurance. They also may be healthier and have 
healthier children and less likely to need Medicaid and therefore less likely to enroll in Medicaid. Further study is required to sort out these possibilities.

What are the implications of these findings? Mostly, the significantly smaller adverse consequences found here as compared to other studies weaken the argument that PROWRA and Medicaid has failed to provide insurance to low-educated women who have exited welfare. For example, Kronebusch (2001) states: "The evidence ... indicates that the states have largely failed in the task of protecting Medicaid coverage of lowincome children (p.110)." In light of our findings, this appears to be somewhat of an overstatement. It is true that declines in the welfare caseload have adversely affected health insurance coverage of low-income women and children, but the effects are not as large as previously thought and they do not suggest a general failure of the Medicaid program, as implied by Kronebusch (2001). Moreover, they are apparently not solely due to changes in government policy, but also because of declines in the caseload related to other factors such as better economic conditions.

The relatively small effects also suggest that welfare reform and the declines in the welfare caseload has not led to a significant decrease in access to health care that may adversely impact the health of low-income families. Of course, some families who have become uninsured as a result of not being on welfare will suffer some financial hardship and possibly some adverse health consequences. However, the relatively small increase in the proportion of low-income families without insurance associated with welfare reform does not suggest that there was a fundamental problem with the safeguards provided in PRWORA to protect health insurance coverage of former welfare recipients. This is particularly true since some portion of uninsured persons is eligible for Medicaid and will enroll in the program at the time medical services are required.

Similarly, the results of this study weaken the argument that cite the loss of health insurance as a consequence of welfare reform as justification for an expansion of Medicaid and the State Children's Health Insurance Program (SCHIP) to adults (Holahan and Weil 2001). Proponents of this argument suggest that the large number of uninsured welfare "leavers" illustrates the problem of relying on the labor market to provide health insurance coverage. But the smaller effects found in this study suggest that many women who were deterred from entering or who left welfare remained insured, particularly those induced to leave welfare because of government policies, either by using their transitional Medicaid benefits, or by obtaining employer-sponsored 
insurance. Indeed, some may argue that these findings show that low-income workers may have more opportunity to obtain employer-sponsored insurance than was previously thought possible. Currie and Yelowitz (2000) show that among working single mothers, over 60 percent were covered by private insurance in 1996, a figure that has undoubtedly increased because of welfare reform. Currie and Yelowitz (2000) also show that over 75 percent of low-educated workers are offered employer-sponsored health insurance. So an alternative to expanding Medicaid to near-poor adults is to help low-income workers buy into employer-sponsored insurance. This may be a more cost effective way to increase health insurance coverage and protect health than expanding Medicaid and SCHIP, which basically provide a voucher for free and unlimited health care that results in a significant amount of over utilization (i.e., moral hazard), and which risks causing many families with employer-sponsored insurance to drop such insurance (Cutler and Gruber 1996).

Acknowledgement: The authors thank Timothy Goodspeed, Michael Grossman, Ted Joyce, Sanders Korenman, Robert Schoeni, and David Cutler for helpful suggestions. 


\section{References}

Bertrand, M., Duflo, E., and Mullainathan, S. 2002. "How much should we trust difference-in-differences estimates?" NBER WP 8841. Cambridge, MA: National Bureau of Economic Research.

Blank, R. 2002. "Evaluating welfare reform in the United States." Journal of Economic Literature 40(4):1-43.

Chavkin, W., Romero, D., and Wise, PH. "State welfare reform policies and declines in health insurance." American Journal of Public Health 90(6):900-908.

Council of Economic Advisers, 1999. "Technical report: The effects of welfare policy and economic expansion on welfare caseloads: An update." Washington, D.C: Executive Office of the President of the United States.

Cunningham, P.J., Schaefer, E., and Hogan, C. 1999. "Who declines employer-sponsored health insurance and is uninsured?" Issue Brief 22, Washington,DC: Center for Studying Health System Change.

Currie, J., and Yellowitz, A. 2000. "Health insurance and less skilled workers." In Finding Jobs: Work and Welfare Reform, eds. Card, D., and Blank, R.M., New York: Russell Sage Foundation.

Currie, J., and J. Grogger. 2002. "Medicaid expansions and welfare contractions: offsetting effects on prenatal care and infant health." Journal of Health Economics 21(2): 313-336.

Cutler, D., and Gruber, J. 1996. "Does public insurance crowd out private insurance?" Quarterly Journal of Economics 111:391-430.

Dubay, L., and Kenney, G. 1996. "Did the Medicaid Expansions For Pregnant Women Crowd Out Private Coverage?” Washington D.C.: The Urban Institute. Unpublished Manuscript.

Ellwood, M. 1999. "The Mediciad eligibility maze: coverage expands but enrollment problems persist." Assessing the New Federalism Occasional Paper \#30. Washington, DC: Urban Institute.

Families USA Foundation. 1999. "Losing Health Insurance: the Unintended Consequences of Welfare Reform." Washington, DC: The W.K. Kellogg Foundation, the George Gund Foundation and the Nathan Cummings Foundation: May 1999.

Garrett, B. and Holohan J. "Health insurance coverage after welfare." Health Affairs. Jan-Feb. 2000.

Garrett, B. and Hudman, J. 2002. "Women who left welfare: Health care coverage, access and use of health services." The Kaiser Commission on Medicaid and the Uninsured, Washington, DC.

Gladden, T., and Taber, C. 2000. "Wage progression among less skilled workers." In Finding Jobs: Work and Welfare Reform, eds. Card, D., and Blank, R.M., New York: Russell Sage Foundation.

Grogger, Jeff, Lynn Karoly, and Jacob Klerman. 2002. Consequences of welfare reform: A research synthesis. DRU-2676-DHHS.

Guyer, B. 2000. "Medicaid and Prenatal Care: Necessary but Not Sufficient." Journal of the American Medical Association 264:2264-2265.

Holahan, J., and Weil, A. 2001. "Health insurance, welfare and work." Welfare Reform and Beyond: Policy Brief, Washington, DC: Brookings Institute.

Joyce, T, Kaestner, R., and Korenman, S. 2002. "Welfare reform and non-marital fertility in the 1990s." unpublished manuscript, Baruch College of the City University of New York, NY.

Kronebusch, K. 2001. "Medicaid for children: Federal mandates, welfare reform, and policy backsliding." Health Affairs, 20:97-111.

$\mathrm{Ku}$ and Garrett. 2000.'How welfare reform and economic factors affected Medicaid participation: 1984 -96. Discussion Paper, Assessing the New Federalism. Washington, DC: Urban Institute.

Kaushal, N., and Kaestner, R. 2001. "From welfare to work: Has welfare reform worked?" Journal of Policy Analysis and Management, 20(4): 740-761.

Moffitt R, and Slade, E. 1997. Healthcare coverage for children who are on and off welfare. The Future of Children, 7(1):87-98.

Schoeni, R. F. and Blank, R.M. 2000. "What has welfare reform accomplished? Impacts on welfare participation, employment, income, poverty and family structure." National Bureau of Economic Research, Working Paper No. 7627. Cambridge, MA: National Bureau of Economic Research. 
Table 1

Health Insurance Status of Women and Children: 1992-1999

Women Ages 18-44 Years, Education $<=12$ Years; Children Ages 0-14

\begin{tabular}{|c|c|c|c|c|c|c|c|c|c|c|c|c|c|c|c|c|}
\hline \multirow{3}{*}{$\begin{array}{l}\text { Sample Description } \\
\text { Women }\end{array}$} & \multirow{3}{*}{$\begin{array}{l}\text { Sample } \\
\text { Size }^{1}\end{array}$} & \multicolumn{15}{|c|}{ Proportion } \\
\hline & & \multicolumn{3}{|c|}{$\begin{array}{l}\text { Covered by Public } \\
\text { Insurance }\end{array}$} & \multicolumn{3}{|c|}{$\begin{array}{l}\text { Covered by Private } \\
\text { Insurance }\end{array}$} & \multicolumn{3}{|c|}{$\begin{array}{c}\text { Employer Sponsored } \\
\text { Insurance in Own } \\
\text { Name }\end{array}$} & \multicolumn{3}{|c|}{ Covered by Champus ${ }^{2}$} & \multicolumn{3}{|c|}{ Uninsured } \\
\hline & & 1992 & 1996 & 1999 & 1992 & 1996 & 1999 & 1992 & 1996 & 1999 & 1992 & 1996 & 1999 & 1992 & 1996 & 1999 \\
\hline $\begin{array}{l}\text { Target Group } \\
\text { Single mothers }\end{array}$ & 21599 & 0.509 & 0.456 & 0.356 & 0.313 & 0.330 & 0.400 & 0.268 & 0.277 & 0.341 & 0.010 & 0.020 & 0.015 & 0.209 & 0.263 & 0.294 \\
\hline $\begin{array}{c}\text { Comparison Groups } \\
\text { Married mothers }\end{array}$ & 45199 & 0.098 & 0.102 & 0.084 & 0.687 & 0.690 & 0.693 & 0.257 & 0.279 & 0.253 & 0.043 & 0.042 & 0.034 & 0.203 & 0.218 & 0.230 \\
\hline Single, no children & 28412 & 0.169 & 0.181 & 0.146 & 0.507 & 0.516 & 0.524 & 0.323 & 0.282 & 0.293 & 0.016 & 0.022 & 0.025 & 0.337 & 0.334 & 0.347 \\
\hline Children living with & & & & & & & & & & & & & & & & \\
\hline Single Mothers & 35778 & 0.592 & 0.614 & 0.559 & 0.280 & 0.278 & 0.329 & -- & -- & -- & 0.011 & 0.024 & 0.021 & 0.170 & 0.173 & 0.179 \\
\hline Married Mothers & 80726 & 0.130 & 0.210 & 0.209 & 0.667 & 0.636 & 0.649 & -- & -- & -- & 0.041 & 0.042 & 0.034 & 0.202 & 0.189 & 0.170 \\
\hline
\end{tabular}

Notes: ${ }^{1}$ Sample size pertains to the combined total for years 1992-1999.

${ }^{2}$ Including Military Health Care, Indian Health Care, and Champus-Veteran's Affairs. 
Table 2

OLS Estimates of the Effect of AFDC/TANF Caseload, Welfare Policy, Unemployment Rates and State Medicaid Eligibility on the Health Insurance Status of Low-educated, Single Mothers; Women Ages 18-44, Education <= 12 Years

\begin{tabular}{|c|c|c|c|}
\hline Explanatory Variables & Medicaid Coverage & $\begin{array}{l}\text { Employer Sponsored Insurance } \\
\text { in Own Name }\end{array}$ & Uninsured \\
\hline Log Caseload & $\begin{array}{l}0.081^{* *} \\
(0.025)\end{array}$ & $\begin{array}{l}-0.040 \\
(0.029)\end{array}$ & $\begin{array}{l}-0.032 \\
(0.025)\end{array}$ \\
\hline Log Caseload & $\begin{array}{l}0.085^{* *} \\
(0.026)\end{array}$ & $\begin{array}{l}-0.038 \\
(0.029)\end{array}$ & $\begin{array}{l}-0.038 \\
(0.026)\end{array}$ \\
\hline \multirow[t]{2}{*}{ TANF } & $\begin{array}{c}0.027 \\
(0.035)\end{array}$ & $\begin{array}{c}0.005 \\
(0.030)\end{array}$ & $\begin{array}{l}-0.016 \\
(0.021)\end{array}$ \\
\hline & $\gamma_{1}=-0.005$ & $\gamma_{1}=-0.054$ & $\gamma_{1}=0.015$ \\
\hline \multirow[t]{2}{*}{ AFDC Waivers } & $\begin{array}{c}0.015 \\
(0.016)\end{array}$ & $\begin{array}{c}0.015 \\
(0.011)\end{array}$ & $\begin{array}{l}-0.034^{*} \\
(0.016)\end{array}$ \\
\hline & $\gamma_{1}=0.035$ & $\gamma_{1}=-0.088$ & $\gamma_{1}=0.075$ \\
\hline $\begin{array}{l}\text { Medicaid Eligibility } \\
134-184 \% \text { of FPL }\end{array}$ & $\begin{array}{l}-0.020 \\
(0.015)\end{array}$ & $\begin{array}{l}-0.000 \\
(0.012)\end{array}$ & $\begin{array}{l}-0.004 \\
(0.016)\end{array}$ \\
\hline $\begin{array}{l}\text { Medicaid Eligibility } \\
>184 \% \text { of FPL }\end{array}$ & $\begin{array}{c}0.004 \\
(0.016)\end{array}$ & $\begin{array}{c}-0.032 \\
(0.017)\end{array}$ & $\begin{array}{c}0.002 \\
(0.017)\end{array}$ \\
\hline Unemployment Rate & $\begin{array}{c}-0.002 \\
(0.006)\end{array}$ & $\begin{array}{l}-0.002 \\
(0.006)\end{array}$ & $\begin{array}{c}-0.002 \\
(0.006)\end{array}$ \\
\hline Lagged Unemployment Rate & $\begin{array}{c}0.006 \\
(0.005)\end{array}$ & $\begin{array}{l}-0.013 * * \\
(0.004)\end{array}$ & $\begin{array}{c}0.005 \\
(0.005)\end{array}$ \\
\hline
\end{tabular}

Notes: Estimates in top two panels are from separate regressions. Dependent variables are listed in column headings. Each regression controls for family size, other family income, age, race, number of kids and number of young kids, state Medicaid eligibility, unemployment rate - current and one-year lag, state and year fixed effects and real state per capita income. State Medicaid eligibility variables are defined on the basis of Medicaid eligibility for pregnant women. Standard errors (assuming non-independence within states) are in parentheses. $* 0.01<\mathrm{p}=<0.05,{ }^{* *} \mathrm{p}=<0.01$ 
Table 3

Difference-in-differences Estimates of the Effect of AFDC/TANF Caseload, Welfare Policy, Unemployment Rates and State Medicaid Eligibility on the Health Insurance Status of Low-educated, Single Mothers; Women Ages 18-44, Education $<=12$ Years

\begin{tabular}{|c|c|c|c|c|c|c|}
\hline Explanatory Variables & \multicolumn{2}{|c|}{ Medicaid Coverage } & \multicolumn{2}{|c|}{$\begin{array}{c}\text { Employer Sponsored Insurance } \\
\text { in Own Name } \\
\end{array}$} & \multicolumn{2}{|c|}{ Uninsured } \\
\hline Comparison Group & Married Mothers & $\begin{array}{c}\text { Single, } \\
\text { No Kids }\end{array}$ & Married Mothers & $\begin{array}{c}\text { Single, } \\
\text { No Kids }\end{array}$ & Married Mothers & $\begin{array}{c}\text { Single, } \\
\text { No Kids }\end{array}$ \\
\hline Log Caseload & $\begin{array}{l}0.079 * * \\
(0.020)\end{array}$ & $\begin{array}{l}0.061 * \\
(0.029)\end{array}$ & $\begin{array}{l}-0.050 \\
(0.030)\end{array}$ & $\begin{array}{l}-0.048 \\
(0.037)\end{array}$ & $\begin{array}{l}-0.047 \\
(0.035)\end{array}$ & $\begin{array}{l}-0.010 \\
(0.030)\end{array}$ \\
\hline Log Caseload & $\begin{array}{l}0.077^{* *} \\
(0.019)\end{array}$ & $\begin{array}{l}0.062^{*} \\
(0.029)\end{array}$ & $\begin{array}{l}-0.050 \\
(0.033)\end{array}$ & $\begin{array}{l}-0.045 \\
(0.038)\end{array}$ & $\begin{array}{l}-0.055 \\
(0.035)\end{array}$ & $\begin{array}{l}-0.015 \\
(0.030)\end{array}$ \\
\hline TANF & $\begin{array}{c}0.010 \\
(0.028)\end{array}$ & $\begin{array}{c}0.036 \\
(0.036)\end{array}$ & $\begin{array}{l}-0.004 \\
(0.026)\end{array}$ & $\begin{array}{l}-0.014 \\
(0.033)\end{array}$ & $\begin{array}{c}0.005 \\
(0.033)\end{array}$ & $\begin{array}{l}-0.013 \\
(0.028)\end{array}$ \\
\hline & $\gamma_{1}=0.043$ & $\gamma_{1}=-0.058$ & $\gamma_{1}=-0.037$ & $\gamma_{1}=0.002$ & $\gamma_{1}=-0.072$ & $\gamma_{1}=0.028$ \\
\hline AFDC Waivers & $\begin{array}{c}0.010 \\
(0.016)\end{array}$ & $\begin{array}{c}0.011 \\
(0.016)\end{array}$ & $\begin{array}{c}0.024 \\
(0.017)\end{array}$ & $\begin{array}{c}0.012 \\
(0.017)\end{array}$ & $\begin{array}{l}-0.022 \\
(0.016)\end{array}$ & $\begin{array}{l}-0.024 \\
(0.020)\end{array}$ \\
\hline & $\gamma_{1}=0.043$ & $\gamma_{1}=0.025$ & $\gamma_{1}=-0.130$ & $\gamma_{1}=-0.085$ & $\gamma_{1}=0.018$ & $\gamma_{1}=0.065$ \\
\hline $\begin{array}{l}\text { Medicaid Eligibility } \\
134-184 \% \text { of FPL }\end{array}$ & $\begin{array}{l}-0.016 \\
(0.014)\end{array}$ & $\begin{array}{l}-0.021 \\
(0.017)\end{array}$ & $\begin{array}{c}0.003 \\
(0.014)\end{array}$ & $\begin{array}{c}0.007 \\
(0.017)\end{array}$ & $\begin{array}{l}-0.008 \\
(0.017)\end{array}$ & $\begin{array}{l}-0.006 \\
(0.021)\end{array}$ \\
\hline $\begin{array}{l}\text { Medicaid Eligibility } \\
>184 \% \text { of FPL }\end{array}$ & $\begin{array}{c}0.001 \\
(0.017)\end{array}$ & $\begin{array}{c}0.003 \\
(0.018)\end{array}$ & $\begin{array}{l}-0.026 \\
(0.017)\end{array}$ & $\begin{array}{l}-0.025 \\
(0.023)\end{array}$ & $\begin{array}{l}-0.009 \\
(0.020)\end{array}$ & $\begin{array}{c}0.003 \\
(0.020)\end{array}$ \\
\hline Unemployment Rate & $\begin{array}{l}-0.006 \\
(0.006)\end{array}$ & $\begin{array}{l}-0.004 \\
(0.007)\end{array}$ & $\begin{array}{l}-0.003 \\
(0.008)\end{array}$ & $\begin{array}{c}0.002 \\
(0.009)\end{array}$ & $\begin{array}{l}-0.001 \\
(0.007)\end{array}$ & $\begin{array}{l}-0.005 \\
(0.009)\end{array}$ \\
\hline Lagged Unemployment Rate & $\begin{array}{c}0.009 \\
(0.006) \\
\end{array}$ & $\begin{array}{c}0.009 \\
(0.006) \\
\end{array}$ & $\begin{array}{c}-0.018 * * \\
(0.006)\end{array}$ & $\begin{array}{l}-0.014^{*} \\
(0.006)\end{array}$ & $\begin{array}{c}0.003 \\
(0.005) \\
\end{array}$ & $\begin{array}{c}0.003 \\
(0.007) \\
\end{array}$ \\
\hline
\end{tabular}

Notes: See notes to Table 2. All controls are introduced separately for the target and comparison groups. Each regression also controls for state*year effects. $* 0.01<\mathrm{p}=<0.05, * * \mathrm{p}=<0.01$. 
Table 4

OLS Estimates of the Effect of AFDC/TANF Caseload, Welfare Policy, Unemployment Rates and State Medicaid Eligibility on

the Health Insurance Status of Children of Single Mothers; Women Ages 18-44, Education $<=12$ Years; Children Ages 0-14

\begin{tabular}{|c|c|c|c|c|c|c|}
\hline \multirow[t]{2}{*}{ Explanatory Variable } & \multicolumn{2}{|c|}{ Medicaid Coverage } & \multicolumn{2}{|c|}{ Private Insurance } & \multicolumn{2}{|c|}{ Uninsured } \\
\hline & Target Group Only & DD Estimates & Target Group Only & DD Estimates & Target Group Only & DD Estimates \\
\hline Log Caseload & $\begin{array}{c}0.062 * \\
(0.027)\end{array}$ & $\begin{array}{c}0.034 \\
(0.029)\end{array}$ & $\begin{array}{l}-0.048^{*} \\
(0.024)\end{array}$ & $\begin{array}{l}-0.008 \\
(0.030)\end{array}$ & $\begin{array}{l}-0.024 \\
(0.025)\end{array}$ & $\begin{array}{l}-0.037 \\
(0.024)\end{array}$ \\
\hline Log Caseload & $\begin{array}{l}0.070 * * \\
(0.026)\end{array}$ & $\begin{array}{c}0.035 \\
(0.030)\end{array}$ & $\begin{array}{l}-0.044 \\
(0.024)\end{array}$ & $\begin{array}{c}0.000 \\
(0.036)\end{array}$ & $\begin{array}{l}-0.031 \\
(0.023)\end{array}$ & $\begin{array}{l}-0.046^{*} \\
(0.019)\end{array}$ \\
\hline TANF & $\begin{array}{c}0.033 \\
(0.032)\end{array}$ & $\begin{array}{c}0.033 \\
(0.036)\end{array}$ & $\begin{array}{c}0.024 \\
(0.019)\end{array}$ & $\begin{array}{c}0.026 \\
(0.024)\end{array}$ & $\begin{array}{l}-0.036 \\
(0.025)\end{array}$ & $\begin{array}{l}-0.037 \\
(0.041)\end{array}$ \\
\hline & $\gamma_{1}=-0.040$ & $\gamma_{1}=-0.075$ & $\gamma_{1}=-0.124$ & $\gamma_{1}=-0.087$ & $\gamma_{1}=0.089$ & $\gamma_{1}=0.077$ \\
\hline AFDC Waivers & $\begin{array}{c}0.026 \\
(0.015)\end{array}$ & $\begin{array}{c}0.028 \\
(0.016)\end{array}$ & $\begin{array}{c}0.017 \\
(0.009)\end{array}$ & $\begin{array}{l}-0.016 \\
(0.014)\end{array}$ & $\begin{array}{l}-0.023 \\
(0.014)\end{array}$ & $\begin{array}{l}-0.007 \\
(0.016)\end{array}$ \\
\hline & $\gamma_{1}=-0.017$ & $\gamma_{1}=-0.058$ & $\gamma_{1}=-0.101$ & $\gamma_{1}=0.053$ & $\gamma_{1}=0.046$ & $\gamma_{1}=-0.023$ \\
\hline $\begin{array}{l}\text { Medicaid Eligibility Income } \\
50-100 \% \text { of FPL }\end{array}$ & $\begin{array}{c}0.016 \\
(0.013)\end{array}$ & $\begin{array}{c}0.019 \\
(0.014)\end{array}$ & $\begin{array}{c}0.013 \\
(0.012)\end{array}$ & $\begin{array}{c}0.014 \\
(0.016)\end{array}$ & $\begin{array}{l}-0.019 \\
(0.011)\end{array}$ & $\begin{array}{l}-0.024 \\
(0.014)\end{array}$ \\
\hline $\begin{array}{l}\text { Medicaid Eligibility Income } \\
101-133 \% \text { of FPL }\end{array}$ & $\begin{array}{l}0.055^{* *} \\
(0.014)\end{array}$ & $\begin{array}{l}0.044 * * \\
(0.016)\end{array}$ & $\begin{array}{c}0.006 \\
(0.015)\end{array}$ & $\begin{array}{c}0.012 \\
(0.020)\end{array}$ & $\begin{array}{l}-0.046^{* *} \\
(0.013)\end{array}$ & $\begin{array}{l}-0.045 * * \\
(0.015)\end{array}$ \\
\hline $\begin{array}{l}\text { Medicaid Eligibility Income } \\
134-199 \% \text { of FPL }\end{array}$ & $\begin{array}{l}0.039 * \\
(0.018)\end{array}$ & $\begin{array}{c}0.031 \\
(0.017)\end{array}$ & $\begin{array}{c}0.010 \\
(0.013)\end{array}$ & $\begin{array}{l}-0.002 \\
(0.020)\end{array}$ & $\begin{array}{l}-0.031 \\
(0.017)\end{array}$ & $\begin{array}{l}-0.014 \\
(0.015)\end{array}$ \\
\hline $\begin{array}{l}\text { Medicaid Eligibility Income } \\
>199 \% \text { of FPL }\end{array}$ & $\begin{array}{l}0.051 * \\
(0.020)\end{array}$ & $\begin{array}{c}0.044 \\
(0.027)\end{array}$ & $\begin{array}{c}0.007 \\
(0.021)\end{array}$ & $\begin{array}{l}-0.027 \\
(0.033)\end{array}$ & $\begin{array}{l}-0.034^{*} \\
(0.016)\end{array}$ & $\begin{array}{l}-0.005 \\
(0.019)\end{array}$ \\
\hline Unemployment Rate & $\begin{array}{c}0.002 \\
(0.006)\end{array}$ & $\begin{array}{c}0.004 \\
(0.007)\end{array}$ & $\begin{array}{c}0.000 \\
(0.006)\end{array}$ & $\begin{array}{c}0.008 \\
(0.009)\end{array}$ & $\begin{array}{c}0.001 \\
(0.005)\end{array}$ & $\begin{array}{l}-0.001 \\
(0.007)\end{array}$ \\
\hline Lagged Unemployment Rate & $\begin{array}{c}0.002 \\
(0.006)\end{array}$ & $\begin{array}{c}0.002 \\
(0.007)\end{array}$ & $\begin{array}{c}-0.006 \\
(0.004)\end{array}$ & $\begin{array}{c}-0.010 * \\
(0.005)\end{array}$ & $\begin{array}{c}0.001 \\
(0.005)\end{array}$ & $\begin{array}{c}0.003 \\
(0.005)\end{array}$ \\
\hline
\end{tabular}


Notes: Estimates in top two panels are from a separate regression. Dependent variables are listed in column headings. Each regression controls for family size, family income, age, race, number of kids and number of young kids, state Medicaid eligibility, unemployment rate - current and one-year lag, state and year fixed effects and real state per capita income. For the DD estimates, children living with married mothers are the comparison group and all controls are introduced separately for the target and comparison groups. DD regressions also control for state*year effects. Standard errors (assuming non-independence within states) are in parentheses. $* 0.01<\mathrm{p}=<0.05, * * \mathrm{p}=<0.01$ 
Appendix Table 1

OLS Estimates of the Effect of AFDC/TANF Caseload, Welfare Policy, Unemployment Rates and State Medicaid Eligibility on the Health Insurance Status of Low-educated, Married Mothers and Single Women; Women Ages 18-44, Education <= 12 Years

\begin{tabular}{|c|c|c|c|c|c|c|}
\hline \multirow{2}{*}{$\begin{array}{l}\text { Explanatory Variables } \\
\text { Sample }\end{array}$} & \multicolumn{2}{|c|}{ Medicaid Coverage } & \multicolumn{2}{|c|}{$\begin{array}{l}\text { Employer Sponsored Insurance } \\
\text { in Own Name }\end{array}$} & \multicolumn{2}{|c|}{ Uninsured } \\
\hline & Married Mothers & $\begin{array}{l}\text { Single, } \\
\text { No Kids }\end{array}$ & Married Mothers & $\begin{array}{c}\text { Single, } \\
\text { No Kids }\end{array}$ & Married Mothers & $\begin{array}{l}\text { Single, } \\
\text { No Kids }\end{array}$ \\
\hline Log Caseload & $\begin{array}{c}0.002 \\
(0.012)\end{array}$ & $\begin{array}{c}0.020 \\
(0.017)\end{array}$ & $\begin{array}{c}0.010 \\
(0.015)\end{array}$ & $\begin{array}{c}0.008 \\
(0.018)\end{array}$ & $\begin{array}{c}0.015 \\
(0.022)\end{array}$ & $\begin{array}{l}-0.022 \\
(0.024)\end{array}$ \\
\hline Log Caseload & $\begin{array}{c}0.004 \\
(0.013)\end{array}$ & $\begin{array}{c}0.020 \\
(0.017)\end{array}$ & $\begin{array}{c}0.009 \\
(0.015)\end{array}$ & $\begin{array}{c}0.010 \\
(0.018)\end{array}$ & $\begin{array}{c}0.011 \\
(0.022)\end{array}$ & $\begin{array}{l}-0.024 \\
(0.025)\end{array}$ \\
\hline TANF & $\begin{array}{c}0.021 \\
(0.011)\end{array}$ & $\begin{array}{l}-0.011 \\
(0.018)\end{array}$ & $\begin{array}{c}0.006 \\
(0.015)\end{array}$ & $\begin{array}{c}0.020 \\
(0.016)\end{array}$ & $\begin{array}{l}-0.022 \\
(0.017)\end{array}$ & $\begin{array}{l}-0.005 \\
(0.019)\end{array}$ \\
\hline AFDC Waivers & $\begin{array}{c}0.005 \\
(0.007)\end{array}$ & $\begin{array}{c}0.002 \\
(0.011)\end{array}$ & $\begin{array}{l}-0.010 \\
(0.011)\end{array}$ & $\begin{array}{c}0.004 \\
(0.013)\end{array}$ & $\begin{array}{l}-0.016 \\
(0.009)\end{array}$ & $\begin{array}{l}-0.012 \\
(0.011)\end{array}$ \\
\hline $\begin{array}{l}\text { Medicaid Eligibility } \\
134-184 \% \text { of FPL }\end{array}$ & $\begin{array}{l}-0.005 \\
(0.007)\end{array}$ & $\begin{array}{c}0.002 \\
(0.010)\end{array}$ & $\begin{array}{l}-0.006 \\
(0.008)\end{array}$ & $\begin{array}{l}-0.004 \\
(0.014)\end{array}$ & $\begin{array}{c}0.006 \\
(0.007)\end{array}$ & $\begin{array}{l}-0.003 \\
(0.014)\end{array}$ \\
\hline $\begin{array}{l}\text { Medicaid Eligibility } \\
>184 \% \text { of FPL }\end{array}$ & $\begin{array}{c}0.002 \\
(0.006)\end{array}$ & $\begin{array}{l}-0.001 \\
(0.009)\end{array}$ & $\begin{array}{l}-0.007 \\
(0.007)\end{array}$ & $\begin{array}{l}-0.005 \\
(0.012)\end{array}$ & $\begin{array}{c}0.014 \\
(0.009)\end{array}$ & $\begin{array}{c}0.001 \\
(0.013)\end{array}$ \\
\hline Unemployment Rate & $\begin{array}{c}0.004 \\
(0.003)\end{array}$ & $\begin{array}{c}0.002 \\
(0.005)\end{array}$ & $\begin{array}{c}0.002 \\
(0.004)\end{array}$ & $\begin{array}{l}-0.001 \\
(0.007)\end{array}$ & $\begin{array}{l}-0.001 \\
(0.004)\end{array}$ & $\begin{array}{l}-0.001 \\
(0.007)\end{array}$ \\
\hline Lagged Unemployment Rate & $\begin{array}{l}-0.003 \\
(0.003)\end{array}$ & $\begin{array}{l}-0.003 \\
(0.003)\end{array}$ & $\begin{array}{c}0.005 \\
(0.003)\end{array}$ & $\begin{array}{c}0.000 \\
(0.003)\end{array}$ & $\begin{array}{c}0.002 \\
(0.003)\end{array}$ & $\begin{array}{c}0.003 \\
(0.005)\end{array}$ \\
\hline
\end{tabular}

Notes: See notes to Table 2. 
Appendix Table 2

OLS Estimates of the Effect of AFDC/TANF Caseload, Welfare Policy, Unemployment Rates and State Medicaid Eligibility on the Health Insurance Status of Children of Married Mothers; Women Ages 18-44, Education $<=12$ Years; Children Ages 0-14 years

\begin{tabular}{|c|c|c|c|}
\hline Explanatory Variable & Medicaid Coverage & Private Insurance & Uninsured \\
\hline Log Caseload & $\begin{array}{c}0.028 \\
(0.022)\end{array}$ & $\begin{array}{c}-0.041 \\
(0.020)\end{array}$ & $\begin{array}{c}0.013 \\
(0.021)\end{array}$ \\
\hline Log Caseload & $\begin{array}{c}0.027 \\
(0.023)\end{array}$ & $\begin{array}{l}-0.033 \\
(0.022)\end{array}$ & $\begin{array}{c}0.009 \\
(0.021)\end{array}$ \\
\hline TANF & $\begin{array}{c}0.000 \\
(0.014)\end{array}$ & $\begin{array}{c}0.001 \\
(0.018)\end{array}$ & $\begin{array}{l}-0.003 \\
(0.020)\end{array}$ \\
\hline AFDC Waivers & $\begin{array}{l}-0.007 \\
(0.010)\end{array}$ & $\begin{array}{l}0.037 * * \\
(0.011)\end{array}$ & $\begin{array}{l}-0.017 \\
(0.011)\end{array}$ \\
\hline $\begin{array}{l}\text { Medicaid Eligibility Income } \\
50-100 \% \text { of FPL }\end{array}$ & $\begin{array}{l}-0.004 \\
(0.008)\end{array}$ & $\begin{array}{l}-0.000 \\
(0.009)\end{array}$ & $\begin{array}{c}0.006 \\
(0.008)\end{array}$ \\
\hline $\begin{array}{l}\text { Medicaid Eligibility Income } \\
101-133 \% \text { of FPL }\end{array}$ & $\begin{array}{c}0.010 \\
(0.011)\end{array}$ & $\begin{array}{l}-0.004 \\
(0.011)\end{array}$ & $\begin{array}{l}-0.001 \\
(0.008)\end{array}$ \\
\hline $\begin{array}{l}\text { Medicaid Eligibility Income } \\
134-199 \% \text { of FPL }\end{array}$ & $\begin{array}{c}0.006 \\
(0.013)\end{array}$ & $\begin{array}{c}0.015 \\
(0.013)\end{array}$ & $\begin{array}{l}-0.015 \\
(0.012)\end{array}$ \\
\hline $\begin{array}{l}\text { Medicaid Eligibility Income } \\
>199 \% \text { of FPL }\end{array}$ & $\begin{array}{c}0.008 \\
(0.018)\end{array}$ & $\begin{array}{c}0.033 \\
(0.021)\end{array}$ & $\begin{array}{l}-0.025 \\
(0.013)\end{array}$ \\
\hline Unemployment Rate & $\begin{array}{l}-0.003 \\
(0.005)\end{array}$ & $\begin{array}{l}-0.008 \\
(0.005)\end{array}$ & $\begin{array}{c}0.002 \\
(0.005)\end{array}$ \\
\hline Lagged Unemployment Rate & $\begin{array}{c}0.001 \\
(0.004)\end{array}$ & $\begin{array}{c}0.002 \\
(0.004) \\
\end{array}$ & $\begin{array}{c}-0.002 \\
(0.004) \\
\end{array}$ \\
\hline
\end{tabular}

Notes: See notes to Table 4 